\title{
界面 化学 (応用篇)。 II.
}

\author{
中 垣 正 幸 \\ 京都大学薬学部 (京都市左京区吉田下阿達町) \\ Surface Chemistry (Applications). II . \\ Masayuki NAKAGAKI
}

Faculty of Pharmaceutical Sciences, Kyoto University (Sakyo-ku, Kyoto)

\section{$2 ヌ \quad レ$}

\section{$2 \cdot 1$ ヌレの理論}

固体面上に 1 滴の液体をのせたときに，液滴が固体面 上を広がっててれをぬらす場合もあり，広がらずに安定 な液滴のままで存在する場合もある。液滴が小さくて重 力の影響を無視できる場合には図-1 a , b のようになり， また液滴が大きい場合には重力のために液滴の頂上は平 らになり図-1 c のようになる。角度 $\theta$ は接触角 (contact angle）之呼ばれる。接触角の測定には種々の方法が用 いられるが，固体の表面が十分に平滑な場合には図-1 d 飞示す傾斜板法 ${ }^{1), 2)}$ がもっとも適当である。板を上下す るととにより前進接触角と後退接触角が測定される ${ }^{3}$ 。 他の重要な方法は固着液滴法 (sessile drop method) である(4),5)。乙れは水平な固体面上に十分な量の 液をの せたときの液滴の高さの極大值 $h$ を測定し，次式によ。 て接触角を算出するものである。

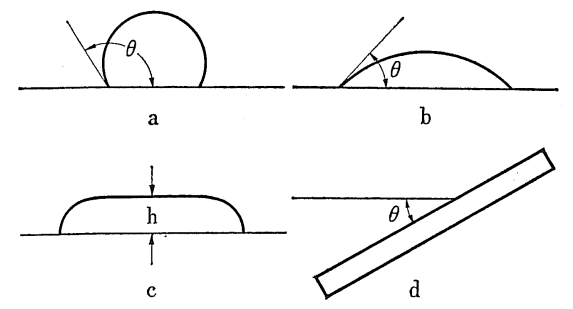

図-1 接 触 角

$\cos \theta=1-\rho g h / 2 \gamma_{L}$

液体 $a$ の上に液滴 $b$ をのせたときに, $b$ が $a$ の上を広 がるととによる自由エネルギーの減少量 $\left(1 \mathrm{~cm}^{2}\right.$ 当たり) $S$ 法㧒張係数 (spreading coefficient) 之呼ばれ

$$
S=r_{a}-\left(r_{b}+r_{a b}\right)
$$

で与えられる。液滴 $b$ が $a$ の上を広がるためには $S$ が 正でなければならない。拡張係数 $S$ は

$$
S=W_{A}-W_{C}
$$

によっても与えられる。ただし $W_{C}$ は凝集仕事 (work of adhesion) と呼ばれ，液体 $b$ を引き離すに要する仕 事 $\left(1 \mathrm{~cm}^{2}\right.$ 当たり) であって次式で与えられる。

$$
W_{C}=2 \gamma_{b}
$$

また $W_{A}$ は粘着仕事 (work of adhesion) と呼ばれ, 液体 $a$ と $b$ を引き離すに要する仕事 $\left(1 \mathrm{~cm}^{2}\right.$ 当たり)で あって,

$$
W_{A}=\gamma_{a}+\gamma_{b}-\gamma_{a b}
$$

で与光られる。

同様の考えは固体の表面にも用いられる。固体と液体 の間の粘着仕事は次式で与えられる ${ }^{3)}$ 。

$$
W_{A(S L)}=\gamma_{S}+\gamma_{L}-\gamma_{S L}
$$

ただし $r_{S}$ は吸着膜の存在しない固体の表面張力であ る。一方 Young の式によれば，

$$
r_{S e}=r_{S L}+r_{L} \cos \theta
$$

ただし $r_{S e}$ は液体の吸着膜で覆われた固体面の表面張力 である。吸着膜の存在による固体の表面張力の低下は表 面圧 $\pi_{e}$ 亿等しく,

$$
\pi_{e}=r_{S}-r_{S e}
$$

その值は Gibbs の财着式に基づき吸着等温線を積分す るととによって求められる。また式 (6)，(7)，(8) 加 ら,

$$
W_{A(S L)}=\pi_{e}+\gamma_{L}(1+\cos \theta)
$$

となりっとれによって粘着仕事が測定される。なお，低 エネルギー面上で広がらない純粹液体については式 (9) の $\pi_{e}$ は無視されるので，

$$
W_{A}=\gamma_{L}(1+\cos \theta)
$$

となる ${ }^{6)}$ 。また，初期および最終の拡張係数はそれぞれ

$$
\begin{aligned}
& S_{L S}=\gamma_{S}-\gamma_{S L}-\gamma_{L} \\
& S_{L S e}=\gamma_{S e}-\gamma_{S L}-\gamma_{L}
\end{aligned}
$$

となり ${ }^{7)}$, Young の式を用いれば

$$
S_{L S e}=\gamma_{L}(\cos \theta-1)
$$

となる。なお，

$$
S_{L S}-S_{L S e}=\pi_{e}
$$

である。

表面張力 $r$ と比表面自由エネルギー $F_{S}$ はしばしば同 一の数值を有するとされているが, 表面張力は

$$
\gamma=(\partial F / \partial A) T, V, n_{i}
$$

であり，比表面自由エネルギーは，

$$
F_{S}=\left(F-F^{\alpha}-F^{\beta}\right) / A
$$


であって，てれらの間にはつぎの関係がある。

$$
F_{S}=r+\sum_{i=1}^{m} \Gamma_{i} \mu_{i}
$$

ただし $\Gamma_{i}$ は成分 $i$ の単位面積当たりの表面過剩量, $\mu_{i}$ は化学ポテンシャルである。したがって純粋液体で は $F_{S}$ と $r$ と等しいが, 吸着が重要な系では両者は等

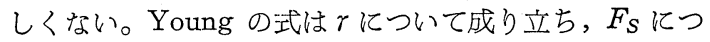
いては成り立たない。

一般に前進接触角は後退接触角よりも大きく ${ }^{1)}$ ，その 差は接触角のヒステリシスと呼ばれる。Harking ${ }^{8)}$ によ ればヒステリシスは測定法の不備によるものというが， しかし実際にはしばしばヒステリシスが認められる。そ の原因は面のア.ラサと吸着 $\left.{ }^{9}\right)$ 一面のヨゴレ一であるとい われる。面のアラサの影響を, 多数のピラミッド型突起 を付したパラフィン面について測定すると，ヒステリシ ス $\left(\theta_{a}-\theta_{r}\right)$ はピラミッドの高さにはほとんど無関係で あるが斜面の傾角 $\phi$ に依存し, 表-1 のように

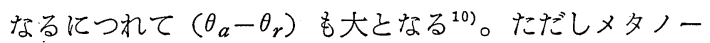
ルはパラフィンに対して溶解性を有するので例外であ る。

表-1 接触角のヒステリシス $\left(\theta_{a}-\theta_{r}\right)$

\begin{tabular}{|c|c|c|c|c|}
\hline 液 & 平滑面 & $\phi=30^{\circ}$ & $\phi=45^{\circ}$ & $\phi=60^{\circ}$ \\
\hline 水 & $11^{\circ}$ & $30^{\circ}$ & $48^{\circ}$ & $64^{\circ}$ \\
\hline $3 M \mathrm{CaCl}_{2}$ & 10 & 24 & 34 & 49 \\
\hline グリ セ リン & 7 & 23 & 44 & 77 \\
\hline エチレングリコール & 7 & 28 & 54 & 103 \\
\hline メチルセロソルブ & 20 & 64 & 82 & 93 \\
\hline メタノ一ル & 15 & 58 & 50 & 0 \\
\hline
\end{tabular}

粗面の実際の表面積が幾何学的表面積の $r$ 倍であると き, Wenzel ${ }^{11)}$ は Young の式をつぎのように書き直 した。

$$
r^{\prime}\left(\gamma_{S}-r_{S L}\right)=r_{L} \cos \theta^{\prime}
$$

これによれば粗面上の接触角 $\theta^{\prime}$ は平滑面上の接触角 $\theta$ に対して次式のような関係にあるてとになる ${ }^{12)} 。$

$$
r \cos \theta=\cos \theta^{\prime}
$$

しかしての式は実験結果に合致しない。

上述の接触角は固体面上での液相と気相の間の接触角 であって, 潤滑, 浮游選鉣, 繊維のヌレなどに関係する ものであるが，固体面上で一つの液体をほかの液体で置 換する問題も工業上重要であり，乙の場合には液相-液 相間の接触角が問題になる。乙の接触角は各液相の空気 $a$ 中での接触角から求められる ${ }^{13)}$ 。ヒステリシスがない 場合には

$$
\begin{aligned}
& \gamma_{S a}-\gamma_{S w}=\gamma_{w a} \cos \theta_{S w a}=A_{S w a} \\
& r_{S a}-\gamma_{S o}=\gamma_{o a} \cos \theta_{S o a}=A_{S o a} \\
& \gamma_{S o}-\gamma_{S w}=\gamma_{w o} \cos \theta_{S w o}=A_{S w o}
\end{aligned}
$$

であるから，

$$
A_{S w a}-A_{\text {Soa }}=A_{\text {Swo }}
$$

が得られる。ヒステリシスがある場合には，水について
前進の場合,

$$
\left.\begin{array}{l}
\gamma_{S a}-\gamma_{S w}=\gamma_{w a} \cos \theta^{a}{ }_{S w a}=A^{a}{ }_{S w a} \\
\gamma_{S^{\prime} a}-\gamma_{S o}=\gamma_{o a} \cos \theta^{r}{ }_{S o a}=A^{r_{S o a}} \\
\gamma_{S o}-\gamma_{S^{\prime}{ }_{w}}=\gamma_{w o} \cos \theta^{a}{ }_{S w o}=A^{a}{ }_{S w o}
\end{array}\right\}
$$

であるから，

$$
A^{a}{ }_{s w a}-A^{r}{ }_{S o a}-\left(\gamma_{S a}-\gamma_{S^{\prime} a}\right)=A^{a}{ }_{S w o}-\left(\gamma_{S w}-\gamma_{S^{\prime} w}\right)
$$

が得られる。ただし $S^{\prime}$ は以前に有機液体と接触してい た固体面を意味する。水が後退する場合についてもてれ 之類似の関係式が得られる。

\section{$2 \cdot 2$ 低エネルギー面のヌレ}

低エネルギー面上における種々の純粋液体の接触角 は，液体の表面張力が小なるほど小であり，したがって 拡張係数 $S_{L S e}$ は式 (12) からもわかるように，負の值 から 0 に近づく ${ }^{6)}$ 。液体の表面張力 $\gamma_{L}$ と $\cos \theta$ の関係 は図-2 のようであって, $\cos \theta=1$ に対する $r_{L}$ の值は

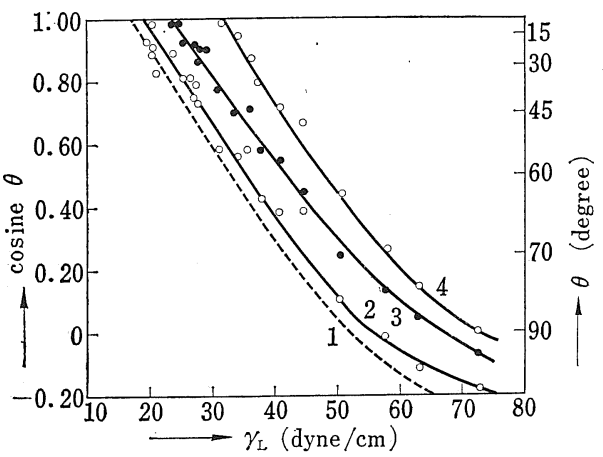

図-2 表面張力と接触角の関係 $\left(20^{\circ} \mathrm{C}\right)$

1 : TFE; $2: 80-20$ Copolymer; $3: 60-40$ Copolymer; $4: \mathrm{KEL}-\mathrm{F}$

臨界表面張力と呼ばれ $r_{C}$ で表わされ，固体面は表面張

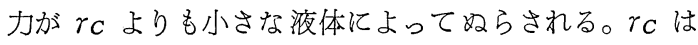
各固体に固有の值であって, フッ素を含む高分子固体で は，図-2 からもわかるように，フッ素含量が多く固体 の表面張力が小さいほど $r_{C}$ の值は小さくなる。粘着仕 事 $W_{A}$ も，一定の液体について，固体のフッ素含量が 多くなると小さくなる。粘着仕事 $W_{A}$ は式 (6) で与え られるから，固体を純粋液体に浸したときの自由エネル ギーの減量を $\Delta F_{S}$ ，すなわち，

$$
\Delta F_{S}=\gamma_{S}-\gamma_{S L}
$$

とすれば，

$$
W_{A}=r_{L}+\Delta F_{S}
$$

となる。したがって一定の固体面について， $\Delta F_{S}$ が液 体の種類に無関係に一定とすれば， $W_{A}$ と $r_{L}$ の関係は 傾斜 $45^{\circ}$ の直線になる。このととは $r_{L}$ の比較的小さい 場合に成り立つてとが知られている。

炭化水素系の固体面については，ポリエチレン，パラ フィン，n-ヘキサトリアコンタンについて比較すると， 固体表面のメチレン基の割合が大きくなる（高分子の分 
子量が大きくなる)と，接触角は小さくなる ${ }^{14)} 。 \cos \theta$ と $r_{L}$ の関係汃ら，前述 図-2 の場合と同様にして 臨界表 面張力を求めることができる。しかしての場合には, $\cos \theta$ と $r_{L}$ の䦎係はポリエチレンでは一つの直線で表 わされるが，パラフィンでは二つ， $n$-ヘキサトリアコン タンでは四つの直線となり，したがって液体の性質によ って臨界表面張力は異なる。 $\cos \theta=1$ のときには， $r_{L}=$ $r_{S e}-\gamma_{S L}$ であるから，固体に対して溶媒効果を有する 液体は $r_{S L}$ が小さいために 臨界表面張力が大きくなる ものと考光られる。

多くの有機液体は低エネルギー面上では広がらない。 てれに対して白金のような高エネルギー面はよく好る が，てれを低表面エネルギー物質で覆えばぬれなくな る。との場合にも $\cos \theta$ と $\gamma_{L}$ の関係は直線となり，乙 れから臨界表面張力 $r_{C}$ が求められる。その值は表-2

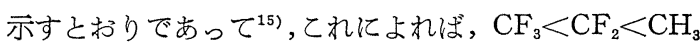
$<$ aromatic ring edge $<\mathrm{CH}_{2}<$ aromatic ring face の順 にぬれやすいととがわかる。また，高エネルギー面上に おいて純粋液体はよく広がるが, 混合液体はしばしば広

表-2 臨界表面張力 $\gamma_{c}$

\begin{tabular}{|c|c|c|c|}
\hline 表 & 面 & 表面の化学構造 & $\begin{array}{c}\gamma_{c} \\
\text { (dyne/cm) }\end{array}$ \\
\hline Perfluorolauric acid & 1 単分子膜 & $\mathrm{CF}_{3}$, 最密充テン & 5.6 \\
\hline $\begin{array}{l}\text { Perfluorobutyric } \\
\text { acid }\end{array}$ & 単分子膜 & " , やや疎充テン & 9.2 \\
\hline Perfluorokerosene & 液体薄膜 & $\mathrm{CF}_{2}$, 一部 $\mathrm{CF}_{8}$ & 17.0 \\
\hline $\begin{array}{l}\text { Polytetrafluoroeth- } \\
\text { ylene }\end{array}$ & 固 体 & & 18.2 \\
\hline Octadecylamine & 単分子膜 & $\mathrm{CH}_{3}$ 最密充テン & 22 \\
\hline$\alpha$-amyl myristic acid & 1 単分子膜 & $\mathrm{CH}_{3}$ と $\mathrm{CH}_{2}$ & 26 \\
\hline 2-ethyl hexyl amine & 単分子膜 & $\mathrm{CH}_{3}$ と $\mathrm{CH}_{2}$ & 29 \\
\hline$n$-hexadecane & 結 & $\mathrm{CH}_{2}$, 一部 $\mathrm{CH}_{3}$ & 29 \\
\hline Polyethylene & 固 & $\mathrm{CH}_{2}$ & 31 \\
\hline Naphthalene & 結晶 & j edge のみ & 25 \\
\hline Benzoic acid & 単分子膜 & edge $と$ face & 53 \\
\hline 2-naphthoic acid & 単分子膜 & edge $\zeta$ & 58 \\
\hline Polystyrene & 固 & $\mathrm{H}_{2}$, 一咅 & $32.8-43.3$ \\
\hline $\begin{array}{l}\text { Polyethylene } \\
\text { terephthalate }\end{array}$ & & $>\mathrm{CH}_{2}$, エス & 43.0 \\
\hline Nylon & 固 & $\mathrm{CH}_{2}$, アミド & $42.5-46.0$ \\
\hline
\end{tabular}

がらない。てれは表面張力の低い方の液体が固体面上に 财着して低エネルギー面を形成するためと考光られる ${ }^{15)}$ 16)。また，クロムメッキ板上に $n$-ヘキサデカン溶液か らの吸着によって脂肪族アミンの単分子膜をつけると, この面上における液体アルカンの接触角は大となる。乙 れは固体面が脂肪族アミンの $\mathrm{CH}_{3}$ 基によって覆われた ためと考えられる。つぎにてれをエーテルまたはべンゼ ンに浸して単分子膜を部分的に脱離させると, 脱離率が $50 \%$ を越元るときに接触角は急激に小さくなる。脱離
率が小さいときには脂肪族アミンの代わりにアルカン分 子が入り込むために，表面は相変わらず $\mathrm{CH}_{3}$ 基で覆わ れており好れにくいが，脱離率が大きくなると脂肪族ア ミンはもはやアルカン分子を垂直には支えきれなくな り，表面に $\mathrm{CH}_{2}$ 基が現われるために齐やすくなるも のと考えられる。このととはアルカンの代わりにトリメ チルベンゼンの接触角を測定するとその值は脱離率の増 加と共に小さくなるととによっても支持される ${ }^{17)}$ 。(図-3 参照)

n-アルキルのアミン, 酸, アルコールなどの有機溶液 は無極性有機液体にぬれない疎油性の吸着膜を固体面上 に生ずる。しかし，一定の溶質一溶媒の組 み合わせの一 定濃度に対してヌレの臨界温度 $T_{w}$ が存在し，それ以 上の温度では面はぬれるようになる。たとえば $\mathrm{C}_{18}$ 化合 物のセタン溶液については， $T_{w}$ は濃度とともに上昇し てある一定值に達し, その值はアルコールく酸くアミン <アミドの順に大である。またその值は炭素数 $N$ に対 して直線的に増大する ${ }^{18)}$ 。いま蹯油性を示すためには吸 着膜が飽和していなければならぬと考光, 吸着エネルギ 一を $U$, 飽和吸着に必要な濃度を $c$ として Boltzmann の式を用い

$$
c=A \exp \left(-U / R T_{w}\right)
$$

とし， $U$ が $N$ に対して直線的に増大するとすれば， $c$ が一定なるためには $b^{2}$ を定数として，

$$
U_{o}+u N=\left(b^{2} R\right) T_{w}
$$

となり, $T_{w}$ と $N$ の直線関係が導かれる。

界面活性剂の水溶液がよく固体面を欢らすのは, 界面 活性剤が蹯水基を固体の方に向け極性基を水の方に向け て吸着されるためと考光られる。しかし，水溶液による ヌレを有機液体の場合と同様に考光, $\cos \theta$ と $\gamma_{L}$ の関 係から臨界表面張力 $r_{C}$ を求めると ${ }^{19)}$, その值はテフロ ンでは 16.5 19.5 dyne/cm，ポリエチレンでは 27.5 31.5 dyne $/ \mathrm{cm}$ であり, 有機液体についての $r_{C}$ とほぼ 一致する。乙れによればヌレ剤の作用は水の表面張力を $r_{c}$ 以下に低下させることである。なお水溶液では $\cos \theta$ と $r_{L}$. 関係に折点が認められ，乙の点に対する界面活 性剤濃度は 表-3 亿示すように CMC と同程度であって $\mathrm{CMC}$ よりもやや小さいてとが知られている。フルオロ カーボン誘導体の水溶液でも ${ }^{20)}$, 同様に $\cos \theta$ 之 $\gamma_{L}$ の 関係に折点が認められる。ただ炭化水素誘導体に比べて

\begin{tabular}{|c|c|c|c|c|c|c|c|}
\hline \multirow[b]{2}{*}{ 界 } & \multirow{2}{*}{\multicolumn{2}{|c|}{ 面 }} & \multirow[b]{2}{*}{ 性 } & \multirow[b]{2}{*}{ 剂 } & \multirow{2}{*}{$\begin{array}{l}\mathrm{CMC} \\
(\mathrm{mol} / \mathrm{l})\end{array}$} & \multicolumn{2}{|c|}{ 濃度 $(\mathrm{mol} / \mathrm{l})$} \\
\hline & & & & & & \begin{tabular}{|l} 
ポリエチ \\
レン
\end{tabular} & テフロン \\
\hline \multicolumn{5}{|c|}{ Na-di-n-butyl sulfosuccinate } & $2 \times 10^{-1}$ & $5.0 \times 10^{-2}$ & $4.2 \times 10^{-2}$ \\
\hline \multicolumn{5}{|c|}{ Na-di-n-octyl sulfosuccinate } & $6.8 \times 10^{-4}$ & $6.8 \times 10^{-4}$ & $4.5 \times 10^{-4}$ \\
\hline \multicolumn{5}{|c|}{$\mathrm{Na}-p$-decyl benzenesulfonate } & $3 \times 10^{-3}$ & $1.2 \times 10^{-3}$ & $1.2 \times 10^{-3}$ \\
\hline \multicolumn{5}{|c|}{$\mathrm{Na}$ lauryl sulfate } & $8 \times 10^{-3}$ & $3.0 \times 10^{-3}$ & $2.7 \times 10^{-3}$ \\
\hline \multicolumn{5}{|c|}{$\begin{array}{l}\text { Cetyltrimethylammonium } \\
\text { bromide }\end{array}$} & $10 \times 10^{-4}$ & $4.3 \times 10^{-4}$ & $3.8 \times 10^{-5}$ \\
\hline
\end{tabular}

表-3 $\cos \theta-\gamma_{L}$ 関係の折点の濃度と $\mathrm{CMC}$ 


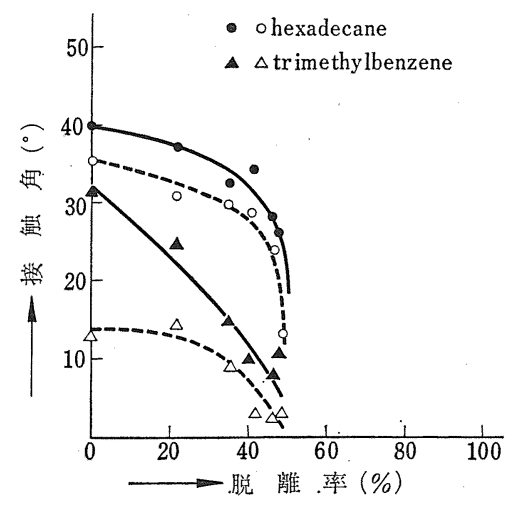

図-3n-octadecylamine 単分子膜の脱離による前進接触角 (一) および後退接触角 (- - - ) の変化

$r_{C}$ の值が小さく，また折点の濃度も：CMC よりが り小さい。

含フッ素有機液体の, 有機液体上における抬張の研究 によれば21)，拡張係数が大であるためには, 分子内に親 油基と疎油基とが存在せねばならず，一般に親油基は炭 化水素鎖であり，蹯油基はフルオロカーボン鎖である。 䟱油性/親油性の比が大となれば，有機液体中での表面 活性, および有機液面上での拡張係数が大となる。適当 なフッ素含量の化合物は $1 \%$ (すなわち約 $0.01 \mathrm{~mol} / l$ ) 程度で有機溶媒の表面張力を約 $50 \%$ 低下させ，また表 面張力の低下度は溶媒の表面張力の大なるほど大きい ${ }^{22)}$ 23)。

\section{$2 \cdot 3$ 毛管ヌレ}

垂直な毛細管を液が上昇する速度は Washburn の式 によれば24,

$$
\frac{d h}{d t}=\left(\frac{2 r \cos \theta}{r}-g h \rho\right) \frac{r^{2}}{8 \eta h}
$$

で与えられる。ただし $r$ は毛細管の半径, $h$ は上昇距 離, $g$ は重力の加速度, $\rho$ は液体の密度である。水平な 毛細管に液体が侵入する速度については, 重力の影響が ないから，

$$
\frac{d h}{d t}=\frac{2 r r \cos \theta}{8 \eta h}
$$

で表わされる。

柾水性モメン糸の界面活性剤水溶液によるヌレは多孔 性疎水性固体のヌレの問題の 1 例である ${ }^{25)}$ 。乙れを 1 種 の毛管ヌレと考えて綿糸を毛細管の束と見なすならば， 糸の長さの方向におけるヌレの速度は $r \cos \theta$ に比例す るが，糸の太さの方向におけるヌレの速度は必ずしも $r \cos \theta$ に比例しない。綿糸の束が沈むに要する時間の 対数はヌレ剂濃度の対数に対して直線的なることが知ら れている ${ }^{26)}$ 。沈下時間の対数はまた $\cos \theta$ に対しても表 面張力に対しても直線的なることが知られている。 Draves-Clarkson sinking test ${ }^{26)}$ にっても Yarnbundle wetting test ${ }^{27}$ によっても沈下時間の対数は $\cos$ $\theta$ に対して直線的となるが，乙のようなモメンの疎水性 はその表面に存在するワックスによるものであり，ワッ クス表面上の接触角と表面張力の関係は, パラフィン鎖. 界面活性剤水溶液については，

$$
\cos \theta=1.68-0.0358 r
$$

である。したがって沈下時間 $t_{S}$ との間には，

$$
\log t_{S}=A+B r
$$

なる直線関係があることになる。この場合の表面張力お よび接触角は液の先端における值であって，その值は界 面活性剂の繊維に対する吸着によって変化する。また, 表面張力と界面活性剤濃度の関係は, Gibbs の吸着式 を積分して，

$$
r=c_{o}-\frac{2.303 R T Z \log c}{N \sigma}
$$

で表わされる。ただし $c_{0}$ は定数， $N$ はアボガドロ数， $\sigma$ は吸着分子 1 個当たりの面積であり， $Z$ は溶質 1 分子 から生ずる粒子数であって非イオン界面活性剤では $Z=$ 1, イオン性界面活性剤では $Z=2$ である。乙れを式(30) に用いれば，

$$
\log t_{S}=A+B C_{o}-B D \log c
$$

となり， $\log t_{s}$ は $\log c$ に対して直線関係をなすてとが 理解される。

\section{$2 \cdot 4$ 高エネルギー面のヌレ}

式 (2) にも示したように，固体面がぬれるための条件 は $r_{S}>r_{S L}+r_{L}$ であり，したがって金属や高融点固体 の清浄な面はすべての液体によってぬらされるはずであ る ${ }^{28)}$ 。このととは, ダイヤモンド, シリカ, 金属などが 数百から数干 $\mathrm{erg} / \mathrm{cm}^{2}$ の表面自由エネルギーを有する のに対して, 大部分の液体や低融点固体（高分子，ワッ クスなど）が 25〜1000 erg/ $\mathrm{cm}^{2}$ の表面自由エネルギー を有することからも理解される ${ }^{29}$ 。しかし前にも述べた ように, 液体または溶質の分子が固体面上に吸着して固 体面を低エネルギー化するならば，固体面はこれらの液

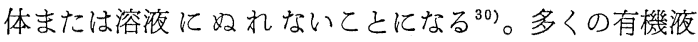
体，例えば直鎖および分枝状の脂肪酸やアルコールは “autophobic”である31)。すなわち液体はそれ自身の吸 着膜上を広がることができない。液体の表面張力が吸着 膜で覆われた固体面の臨界表面張力 $r_{C}$ よりも大きけれ ば液体は広がらない。種々の純粋液体の $18 / 8$ 鋼, シン チュウ, シリカ，サファイア，白金などの表面上におけ る接触角を見ると ${ }^{30)}$, 液体が広がるか否かは液体の表面 張力のみでは定まらぬことがわかるが，しかし，表面張 力が $33.5 \mathrm{dyne} / \mathrm{cm}$ 以上の液体はどの固体面上でも広が らないようである。液状脂肪族炭化水素はそれ自身の吸 着膜が 31 dyne $/ \mathrm{cm}$ (ポリエチレンの值) 以上と考えら れるのに対して, 表面張力は $30 \mathrm{dyne} / \mathrm{cm}$ 以下であるか ら，すべての高エネルギー面上を広がる。またポリメチ ルシロキサンもすべての高エネルギ一面上で広がる。乙 
れに対して autophobic な液体はたとえば塩素化ジフェ ニル, リン酸トリフェニル誘導体, 芳香族炭化水素, ステル，エーテルなどである。純粋液体に少量の極性物 質を添加すると広がらなくなるととはすでに述べた。

金属および酸化物の表面の液体金属によるヌレはハン 多付け，口ウ付け，熱伝導など，または冶金学における 粒子の成長や大きな単結晶の成長なぞ種々の方面で重要 である。いままで述べたヌレの理論はこの場合にもほぼ 成り立つが，液体金属はかなりの化学反応性を有する点 が異なる。反応性はアルカリ金属のように金属自身の性 質による場合もあるが，また金属を液化するのに高温を 要するためでもある。

固体の表面張力は微粒子の溶解熱 ${ }^{22)}$ や比熱 ${ }^{33)}$ の測定に よっても求市られるが，しかしコロイド的大きさの粒子 では結晶格子のヒズミのために表面自由エネルギーのみ ならず熱含量に差を生じているおそれがある ${ }^{34)}$ 。固体の 表面自由エネルギーを正確に定めるには細い針金の高温 クリープの測定が用いられる ${ }^{35}$ （融点から $60^{\circ} \mathrm{C}$ 以内の 温度で測定を行なう)。また, 固体の表面張力は液体に比 べてわずかに高いのみであるから，その值は融液の表面 張力の測定值からも推定される。後者は最大ホウ圧法 ${ }^{36)}$, 付着液滴法 ${ }^{37}$, 愳垂液滴法 ${ }^{38)}$ な゙゙で測定される。液体 金属の固化による表面自由エネルギーの増加量 $\Delta r$ は 1 原子当たりの融解熱を $\Delta h_{f}, 1$ 原子当たりの占有面積を $A_{w}$ とするとき，

$$
\Delta \gamma=\Delta h_{f} / A_{w}
$$

の程度であり, 分子性固体ではその $1 / 8 \sim 1 / 3$ 程度であ る。表-4 に示すように式 (33)を用いて補正した值はク リープ法によって直接測定した值とよく一致する。金属 および金属酸化物では分子間力が大きいために表面エネ ルギーも大きいと考光られ，その值は有機液体の 10 倍 以上である ${ }^{399}$ 。

\begin{tabular}{|c|c|c|c|c|c|}
\hline 金 属 & $\begin{array}{l}\text { 温度 } \\
\left({ }^{\circ} \mathrm{C}\right)\end{array}$ & $\begin{array}{c}\text { 表面張力 } \\
\text { (クリープ法) }\end{array}$ & 結晶面 & \begin{tabular}{|l|} 
式(33)に \\
学表面 \\
張力
\end{tabular} & \begin{tabular}{|l}
$\mid$ 式(33)による \\
直化の際の表 \\
面張力撸加量
\end{tabular} \\
\hline \multirow[t]{2}{*}{ 銀 } & \multirow[t]{2}{*}{900} & \multirow[t]{2}{*}{$1140 \pm 90$} & 100 & 1150 & 220 \\
\hline & & & 111 & 1180 & 250 \\
\hline \multirow[t]{2}{*}{ 金 } & \multirow[t]{2}{*}{1300} & $1400 \pm 65$ & 100 & 1396 & 256 \\
\hline & & $1510 \pm 100$ & 111 & 1438 & 298 \\
\hline \multirow[t]{2}{*}{ 銅 } & \multirow[t]{2}{*}{1050} & 1430 & 100 & 1509 & 329 \\
\hline & & 1670 & 111 & 1560 & 380 \\
\hline \multirow[t]{2}{*}{$\gamma$-鉄 } & \multirow[t]{2}{*}{1400} & \multirow{4}{*}{704} & 100 & 2070 & 370 \\
\hline & & & 111 & 2127 & 427 \\
\hline \multirow[t]{2}{*}{ スズ } & \multirow[t]{2}{*}{150} & & 100 & 765 & 128 \\
\hline & & & 111 & 672 & 35 \\
\hline
\end{tabular}

金属混合物の表面自由エネルギーは表面自由エネルギ 一の低い方の成分に支配される。乙れはての成分が一般 に表面に濃縮されるためである。ただし金属間化合物を 生ずる場合は例外である。たとえばアルカリ金属および
アルカリ土類金属は溶融金属（水銀，スズなど）の表面 張力を低下させる。また, 酸素, イオウ, 窒素などは溶 融鉄の表面張力を低下させ, 表面張力と添加物濃度との 関係から 1 原子の占める面積を求めると酸素は $7.62 \AA^{2}$, イオウは $14.4 \AA^{2}$ となるが ${ }^{40)}$ ，炭素は鉄の表面張力を 変化させない。また, 溶融金属酸化物の混合物の表面張 力と組成の関係は, 有機液体混合物の場合とよく似てい る ${ }^{39)}$ 。

液体金属上における溶融塩の界面張力は 表-5 のよう に十分小さいので, 液体金属上の溶融塩の拡張係数は正 である ${ }^{39}$ 。金属誘導体は一般に金属自身よりも表面張力 が小さいから, 反応性気体は金属の表面張力を低下させ る。不活性気体も物理吸着により表面張力を低下させ 表-5 液体金属上の溶融塩の界面張力と拡張係数

\begin{tabular}{|c|c|c|c|c|c|}
\hline 系 & $\begin{array}{l}\text { 温度 } \\
\left({ }^{\circ} \mathrm{C}\right)\end{array}$ & \multicolumn{4}{|c|}{ 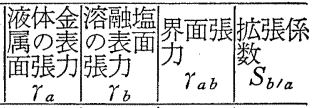 } \\
\hline \multirow[t]{2}{*}{$\mathrm{Cu}-\mathrm{Cu}_{2} \mathrm{~S}$} & 1131 & 1120 & \multirow{6}{*}{100} & 90 & \\
\hline & 1215 & & & 76 & \\
\hline $\mathrm{Sn}-\mathrm{SnCl}_{2}$ & 275 & 615 & & 342 & 173 \\
\hline $\mathrm{Sn}-\left(\mathrm{ZnCl}_{2}+\mathrm{NH}_{4} \mathrm{Cl}\right)$ & 250 & 616 & & 420 & \\
\hline \multirow[t]{2}{*}{$\mathrm{Pb}-\mathrm{PbCl}_{2}$} & 510 & 430 & & 190 & \\
\hline & 600 & 423 & & 170 & \\
\hline \multirow[t]{2}{*}{$\mathrm{Pb}-\left(\mathrm{PbCl}_{2}+\mathrm{KCl}\right)$} & 460 & 434 & 105 & 228 & 101 \\
\hline & 600 & 423 & 95 & 208 & 120 \\
\hline \multirow[t]{2}{*}{$\mathrm{Cd}-\mathrm{CdCl}_{2}$} & 605 & 585 & 77 & 4 & 504 \\
\hline & 725 & 573 & 75 & 3.9 & 494 \\
\hline \multirow{2}{*}{$\begin{array}{l}\mathrm{Cd}-\left(0.32 \mathrm{CdCl}_{2}+0.68\right. \\
\mathrm{KCl})\end{array}$} & 605 & 585 & 81 & 131 & 373 \\
\hline & 725 & 573 & 71 & 125 & 377 \\
\hline
\end{tabular}

る。またたとえば炭素, 窒素, イオウ, 酸素などは鉄と 酸化アルミニウムの界面張力を低下させる ${ }^{40)}$ 。

固体金属の液体金属によるヌレについては信頼すべき 測定值が得にくい。乙れは高温のために酸化被膜を生ず るためである。酸化被膜は金属の表面張力を低下させる けれども，永久にヌレを妨げるわけではなく，多くの液 体金属は拡散によって，またはピンホールを通って酸化 被膜の下に入りとみてれを下地の金属固体面からはがし てしまう。また，液体金属と下地の金属が金属間化合物 または固溶体をつくるときには，初期には必ずよくぬれ る。界面におけるある特定の金属間化合物のみがよく刚 れ，温度を上げるとての金属間化合物が分解するために ぬれなくなるとともある。たとえばスズー鉛合金は銅の 表面で $380^{\circ}$ 以下で安定な被膜をつくるが，乙の温度， すなわち銅ースズー $\eta$ 相の分解温度以上では被膜は不安定 になり液滴となる ${ }^{41)}$ 。

\section{3 潤 滑}

潤滑は 3 種に分類される。第 1 は水力学的潤滑であっ て，ての場合には二つの金属面は流体層によって完全に へだてられている。第 2 は境界潤滑であって, 二つの金 
属面は接しているが，それらの間には吸着膜があって金 属間の燒着が妨げられている場合である。第 3 は極限境 界潤滑であって，第 2 の境界潤滑に似ているがより撖し い条件であり，少なく之も一方の金属面化学吸着する 潤滑剤のみが金属間の焼着および消耗を妨ざうる。第 2 ， 第3のものが界面化学的現象である。

\section{$3 \cdot 1$ 吸着気体の影響}

摩擦係数 $\mu$ は, 摩擦力を $F$, 荷重を $W$ とするとき,

$$
\mu=F / W
$$

で与えられる。普通に空気中で洗浄した固体面では $\mu=$ 0.5 1 であるが，乙の面には酸素，水蒸気なぞが数分 子層にわたって吸着しており，てれを真空加熱によって 取り除くと $\mu$ の值は 100 以上になる。とのようにして清 浄にした金属面は, 酸素に触れると摩擦係数が $\mu=1$ 付 近まで低下する。水蒸気でも同様に $\mu$ の值が低下し，凍 結によって水蒸気を除去すると カプロン酸の蒸気によっても同様に $\mu$ の值が低下する。 また，塩素，硫化水素などによっても值は低下する が,この場合には数百度に加熱しなければ脱着しない ${ }^{42)}$ 。

\section{2 長鎖化合物の効果}

極性有機化合物が摩擦係数を低下させることは多くの 人によって示されていたが， Langmuir ${ }^{43)}$ は脂肪酸の単 分子膜が摩擦係数を著しく低下させることを見出し，そ の後さらに，ステアリン酸カルシウムまたはバリウムの 累積膜は潤滑作用は単分子膜と同程度であるが単分子膜 よりも耐久性がはるが大きいととを見出した。累積膜 は人為的にのみ作られるものであるが，単分子膜は通常 の実用的条件のもとで容易に形成されるものであって， Zisman らは ${ }^{44}$ 三つの方法で作った単分子膜が同一の結 果を与えるととを示した。第 1 は溶液からの吸着, 第 2 は気相からの吸着，第 3 は溶融固体による方法である。 脂肪族アミン誘導体の飽和吸着膜について, 摩擦係数 $\mu$ 之その面上におけるヨウ化メチレンの接触角 $\theta_{\text {max }}$ を測 定したところ ${ }^{45}$, 直鎖の炭素数 $N$ が同一であればアミ ンの塩酸塩も第一アミンも第三アミンも第四アンモニウ 厶塩も同一の $\mu$ の值を与え，かつ $N$ が大となるにつれ て $\mu$ は低下し， $N \geq 14$ で $\mu$ の值は一定になることが 見出された。また第四アンモニウム塩以外のものは， $N$ が同一であ机ば同一の $\theta_{\max }$ の值を与え, かつ $\theta_{\max }$ は $N$ の増加につれて増大し， $N \geq 14$ で一定となるてとが 見出された。同样の研究は他の同族列についても行なわ れている。

表面積の耐久性をみるために，単分子膜をつけたスラ イドグラスの上を，荷重をかけた清浄な鋼球を何度も往 復させると， $\mu$ は次第に上昇する ${ }^{45)}$ 。 $5000 \mathrm{~g}$ の荷重で 30 回横断させても第一アミンでは $\mu$ の值は変化しなかった が，第四アンモニウム塩は 5 回で $\mu=0.05$ から $\mu=0.40$ まで上昇した。脂肪酸同族列については，炭素原子数の
大なるものほど耐久性が大きく，図-4 に示すように， 炭素数 13 以上の脂肪酸の単分子膜は荷重 $1000 \mathrm{~g}$ で 10 回以上の横断に耐えるが，炭素数 13 以下では炭素原子 数 $N$ が小になるにつれて耐久性も低下する。図-4に対 応して, 脂肪酸の単分子膜は $8 \leq N \leq 12$ では液状, 13 $\leq N \leq 15$ では無晶形または塑性固体状，N $N 16$ では結

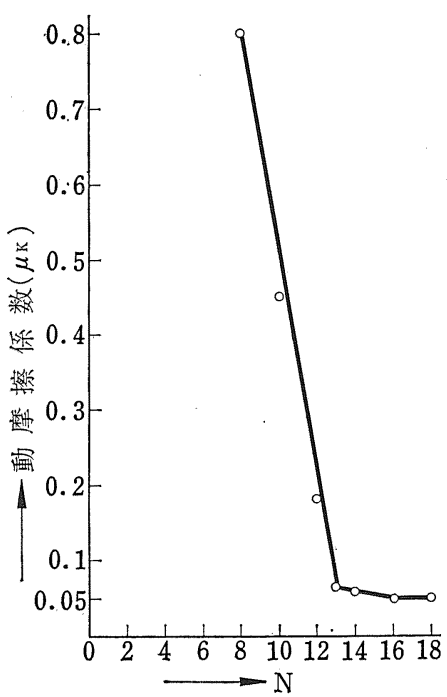

図-4 脂肪酸単分子膜上を荷重 $1000 \mathrm{~g}$ で 10 回横断させたのち の動摩擦係数

晶状と考光られている。ステンレススチール面上の脂肪 酸単分子膜はガラス面に比べて耐久性が小さい(46)。乙の ような結果によれば，単分子膜が十分な潤滑作用を示す ためには，膜は固体膜であって分子間凝集力が大きく， 極性基は下地佁強く結合するものであり，外側の末端基 は表面自由エネルギーのなるべく小さい $-\mathrm{CF}_{3},-\mathrm{CF}_{2} \mathrm{H}$, $-\mathrm{CH}_{3}$ などであり, 単分子膜を生ずる際に溶媒分子の混 合膜になると凝集エネルギーも粘着エネルギーも低下す るから溶媒を含まない単分子膜を生ずるととなどが必要 である ${ }^{46) 。 ~}$

\section{$3 \cdot 3$ 極限境界潤滑}

金属の切削は極限境界潤滑の研究に適当である。新し く切り出された金属面は清浄で酸素の吸着膜もなく，ま た内部ヒズミが多く, 温度も $1000^{\circ} \mathrm{F}$ を越すととが多く, 反応性に富んでいる ${ }^{47)}$ 。18-4-1 高速鋼の刃物 (rake angle $\left.\alpha=15^{\circ}\right)$ でアルミニウムを切削したときの chip length ratio $r_{e}$, または次式から求められる shear angle $\phi$ :

$$
\tan \phi=\frac{r_{e} \cos \alpha}{1-r_{e} \sin \alpha}
$$

と摩擦係数 $\mu$ との関係をみると， $\mu$ が減少するにつれ て $r_{e}$ およびфは增大する。したがって $r_{e}$ または $\phi$ に よって潤滑効果を測るととができる。種々の液体を比較 すると， disulfide，メルカプタン，長鎖エステルなどは 
特に摩擦係数を低下させるのに有効であった。最低值 $\mu$ $=0.237$ は $n$-ラウリルメルカプタンについて得られた。 同族列では鎖長が大となるにつれて ルミニウムと反応しやすいものほど低い，の值を与え た。

\section{（昭和 39 年 10 月 27 日受理） 文献}

1) N.K. Adam, "The Physics and Chemistry of Surfaces" (1941), Oxford Univ. Press, London

2) F.M. Fowkes, W.D. Harkins, J. Am. Chem. Soc., 62, 3377 (1940)

3) W.D. Harkins, "The Physical Chemistry of Surface Films" (1952), Reinhold Publishing Corp., New York

4) Poynting, Thomas, "Properties of Matter", Text" book of Physics, p. 156 (1905), London

5) J.F. Paddy, "Proc. Intern. Congr. Surface Activity", 2nd., Vol. 3 (1957) Butterworth, London

6) H.W. Fox, W.A. Zisman, J. Colloid Sci., 7, 109 (1952)

7) G.E. Boyd, H.K. Livingston, J. Am. Chem. Soc., 64, 2383 (1942)

8) F.W. Fowkes, W.D. Harkins, J. Am. Chem. Soc,, 62, 3377 (1940)

9) F.E. Bartell, J.T. Smith, J. Phys. Chem., 57, 165 (1953)

10) F.E. Bartell, J.W. Shepard, J. Phys. Chem., 57, 211, 455, 458 (1953)

11) R.N. Wenzel, Ind. Eng. Chem., 28, 988 (1936); J. Phys. Chem., 53, 1466 (1949)

12) J.L. Moilliet, B. Collie, "Surface Activity" (1951), D. Van Nostrand Co., New York.

13) B.R. Ray, F.E. Bartell, J. Phys. Chem., 57, 49 (1953)

14) H.W. Fox, W.A. Zisman, J. Colloid Sci., 7, 428 (1952)

15) H.W. Fox, E.F. Hare, W.A. Zisman, J. Colloid Sci., 8, 194 (1953)

16) A.H. Ellison, W.A. Zisman, J. Phys. Chem., 58, 503 (1954)

17) L.S. Bartell, R.J. Ruch, J. Phys. Chem., 63, 1045 (1959)

18) J.E. Brophy, W.A. Zisman, Am. N.Y. Acad. Sci., 53, 836 (1951)

19) M.K. Bernett, W.A. Zisman, J. Phys, Chem., 63, 1241 (1959)

20) M.K. Bernett, W.A. Zisman, J. Phys. Chem., 63, 1911 (1959)

21) N.L. Jarvis, W.A. Zisman, J. Phys. Chem., 63, 727
(1959)

22) N.L. Jarvis, W.A. Zisman, J. Phys. Chem., 64, 150 (1960)

23) N.L. Jarvis, W.A. Zisman, J. Phys. Chem., 64, 157 (1960)

24) E.W. Washburn, Phys. Rev., 17, 273 (1921)

25) F.M. Fowkes, J. Phys. Chem., 57, 98 (1953)

26) C.Z. Draves, R.G. Clarkson, Am. Dyestuff Reptr., 20, 201 (1931)

27) S.M. Edelstein, C.Z. Draves, Am. Dyestuff Reptr., 38, 343 (1949)

28) W.D. Harkins, A. Feldman, J. Am. Chem. Soc., 44, 2665 (1922)

29) W.D. Harkins, in Alexander's "Colloid Chemistry", Vol. 6 (1946), Reinhold Publ. Corp., New York.

30) H.W. Fox, E.F. Hare, W.A. Zisman, J. Phys. Chem., 59, 1097 (1955)

31) E.F. Hare, W.A. Zisman, J. Phys. Chm., 59, 335 (1955)

32) R. Fricke, Kolloid-Z., 96, 213 (1941); R. Fricke, in "Handbuch der Katalyse", Vol. 6, p. 108 (1943), J. Springer, Vienna.

33) G. Jura, J. Chem. Phys., 12, 1335 (1949)

34) G.F. Hüttig, Kolloid-Z., 124, 160 (1951)

35) H. Udin, in "Metal Interfaces", p. 114 (1952), Amer. Soc. for Metals, Cleveland, Ohio; H. Udin, A.J. Shaler, J. Wulff, J. Metals, 1, 186 (1949); 3, 1206, 1209 (1951)

36) F. Sauerwald, B. Schmidt, F. Pelka, Z. anorg. Chem., 223, 84 (1935)

37) G. Becker, F. Hardus, H. Kornfeld, Arch. Eisenhuttenw, 20, 363 (1949); W.D. Kingery, M. Humenik, Jr., J. Phys. Chem., 57, 359 (1953)

38) J.K. Davis, F.E. Bartell, Anal. Chem., 20, 1182 (1948)

39) A. Bondi, Chem. Rev., 52, 417 (1953)

40) F.A. Halden, W.D. Kingery, J. Phys. Chem., 59, 557 (1955)

41) G.L. Bailey, H.C. Watkins, J. Inst. Metals, 80, 57 (1951)

42) F.P. Bowden, Ann. N.Y. Acad. Sci., 53, 805 (1951); F.P. Bowden, J.E. Young, Nature, 164, 1089 (1949)

43) I. Langmuir, Trans. Faraday Soc., 15, 62 (1920)

44) O. Levine, W.A. Zisman, J. Phys. Chem., 61, 1068 (1957)

45) O. Levine, W.A. Zisman, J. Phys. Chem., 61, 1188 (1957)

46) R.L. Cottington, E.G. Shafrin, W.A. Zisman, J. Phys. Chem., 62, 513 (1958)

47) M.C. Shaw, Ann. N.Y. Acad. Sci., 53, 962 (1951) 